\title{
Nationalism in Muslim Community in India During the War of 1857: A Brief Outlook on Indian Freedom Movement
}

Amjad Hussain Laskar*

Research Scholar, Department of Arabic, Guwahati University, Assam, India

DOI: $\underline{10.36348 / \text { sjhss.2020.v05i09.003 }}$

| Received: 08.01.2020 | Accepted: 10.02.2020 | Published: 16.09.2020

*Corresponding author: Amjad Hussain Laskar

Abstract

Nationalism is a perspective that denotes the common interests of the people dwelled in a geographical area of the globe. Nationalism comes into existence when the people of a geographical area unite themselves emotionally as well as socially and politically in a single cause especially with the aim of gaining and maintaining the nation's sovereignty over the place where they lived in. nationalism is an idea that prevent the human physiology to live the life of slavery under the foreign authority. It teaches a nation to refrain from accepting any foreign superiority on their people and promote the full power and right to govern the people of a nation without having any interference from the people or authority came from outside. Though the concept of modern nationalism was emerged in India in the early nineteen century but it never denotes that the people of early India were lack of national feelings. Many colonial historians by their historiography tried to prove that the fight fought by Indian Muslim was absence of Nationalism and deliberately exaggerated that the revolution performed by Indian Muslim were the result of Islamic fanaticism but the truth never be hidden as many primary resources regarding the national movement of India were preserved in national achieve of India which denotes that most of the revolution done by Muslim in per-nineteenth century were based on national feelings. Here in this paper I would proceed my work basing on the documents preserved in national archive of India which were more authentic and strong evidence of the contribution of Muslim community to the freedom movement of India based on nationalism. Keywords: Nationalism, colonialism, fanaticism, politic of text and British historiography and dichotomy on religious identity.

Copyright @ 2020: This is an open-access article distributed under the terms of the Creative Commons Attribution license which permits unrestricted use, distribution, and reproduction in any medium for non-commercial use (NonCommercial, or CC-BY-NC) provided the original author and source are credited.

\section{INTRODUCTION}

Every event has its contemporary or subsequent historiography and it is seen in most of the historical occurrence that a lot of perspective grew around a past event. The history of Indian freedom struggle was not deferent from the same action. Many perspectives were grew around our national movement but it was seen in most of the subsequent historiography that they interpreted the content of this event either on constructed memory or according to the perspective of colonial writing because during the preindependence period our inland writer seldom went through the history of Indian freedom movement because to rise voice against British during the British raj was regarded as a crime and such circumstance a rare portion of Indian intellectual dared to attempt on this side of historiography which uncover the British atrocities and maltreatments with Indian Native. On the other hand whatever history written by colonial historiographer was seemed to be more contradictory of those inland supplements preserved in national achieve of India in the shape of Mutiny papers, news papers, letters, revolutionary pamphlet Mughal court and administrational proclamations. To discover the actual fact regarding freedom struggle of India one should juxtapose the inland resources with the colonial writings. My research is based on that scientific methodology which resembles the entire inland supplement with those of time serving historical contents. Most of the British writers seen creating dichotomous policy and focusing more on religious identity rather than Indian nationalism while interpreting the Indian freedom movements yet the documents preserved in national archive of India demonstrate the matter complete opposite to their perspectives.

Muslim community of India from the very begging fomented a kind of detest against British colonial system and in course of time this disfavor and discontent took the shape of Indian nationalism. 
Muslim entered in India long before the British discovered Indian Territory and accepted India as their home land. However among those foreigners who established empire in India and adopted it as their own motherland were the Mughals who tried their heart and soul to develop Indian political, social, cultural, economical and commercial sectors. One of the most chirming characteristics that isolate Mughal kings from other foreigners was their devotion and reverence towards their new adopted land. They had never seen plotting India as other European foreigners did. History bears witness that Mughals provided India the prestigious honor and change it to one of the most powerful and economically sound country in that contemporary world. The people of the entire glove look up India with submissive eyes and praised them for their wonderful deeds. The case for India an account of the most rewound European historian Will Durant admitted as follows:

The Mohammedan authority those raider came to stay, and their successors call India their home, what they took in taxes and tribute they used in India, developing its industries and resources, adorning its literatures and arts if the British had done likewise, India would to-day be a flourishing nation but the piesent plunder has now gone on beyond bearing, year by year it is destroying one of the greatest and gentlest peoples of history [1].

It is worth mentioning that the Muslim settlements in India does not originate from Turkish envision. Turk came in India in the early tenth century as invaders but India has its own inscriptional data and primary sources which are significant enough to prove that Muslim in India was as ancient as the revelation of Islam on earth and the influence of Islam in India was not as a result of forced conversion. Historian V.K Jain pointed out it as telling us that "in fact, long before the Truks had established the sultanate in northern India, the Islamic influences were at work in western India, mainly through the mercantile activities of Arab traders"[2]. But to create dichotomy among the Indian masses the British referred the event of Samantha and tried to prove that the Muslim invasion of India was a trauma and symbol of Hindu subjugation but the inland resources proved that the Muslim community of India had been always devoted to their motherland India and time and again proved their love devotion and affection by sacrificing their live and wealth for the sake of motherland. Here in this topic I would focus on the contribution of Indian Muslim to the freedom movement of India.

\footnotetext{
${ }^{1}$. Durant Will, The case for India first edition by simon and Schuster, ino 386 fourth ave, New York 1930, latest edition, neha publishers and distributors, Daryaganj Delhi. 2019. p.55.

2. Jain ,V.K., Trade and Traders in western India, Munshiram Manoharlal Publishers Pvt Ltd. New Delhi. 1990, pp 85- 81.
}

\section{Research Methods and Materials}

The topic based on "Nationalism in Muslim community in India during the pre-independence period: A brief outlook on Indian freedom movement" is to be carried out with the scientific research methodology. It was a historical research and to carry out and proceed to the final finding I would like to use some primary and secondary sources and keep all the materials in a juxtaposition and re-examine the subsequent historiography of freedom movement based on the documents found in the pre-independent period. Among these resources the most remarkable were the trial papers, proceeding papers, revolutionary pamphlet, letters from the British government and Mughal court and petitions from the native people to the British and Mughal administrations. Moreover I collect most of the Urdu and Persian newspapers of pre-independent India to understand the circumstances under which the freedom fight was carried out by Muslim community and resembled them with each other to find out the real facts behind the historiography of colonial history.

\section{Result and Discussion \\ The emergence of the perspective of nationalism in Indian masses}

From the day immemorial India had been a domain of versatile human race. Among them the most remarkable were the people migrated from the side of East Asia and western Asia and south Asia and Europe. But deference between other and European race was that the European race never excepted India as to be their home land rather they used their rapacious cruelty and endless extraction on Indian wealth as well as oppressed and suppress the Indian people in both physically and intellectually. For these reason both Muslim and non-Muslim natives fomented a disfavor against the alien race occupied their territories and in course of time this detest took the shape of nationalism among the Indian masses but by their historiography British tried to hide the fact that lead the Indians towards the revolutionary movement against British. They wrote their history according to their test, tradition and perspective. They tried to refrain themselves from expressing attribute of nationalism while they wrote the history of Indian past and always seen playing the filthy politics of religious identity and they succeeded in their attempt because most of the anti-British movement of pre-independent period were interpreted as religious radicalism. Even they left no stone unturned to prove the war of 1857 as to be the result of religious fundamentalism of some Sepoys who fought fight against British due to the religious narrowness. But the materials from National archive of India shows another picture of the same history. These documents clearly bear evidences of the existence of national feelings in Indian masses in the war of 1857. The column of the news paper Delhi Urdu Akhbar of 1857 preserved in national archive of Indian denotes the existence of national feelings. The editor of the 
newspaper Maulana Md Baqr issued a column addressing its subscribers that: He wrote addressing them:

"Oh my countrymen looking at the strategy and devious cleverness of the English, their ability to make arrangements and to order the world in the way they wish, the wide expanse of their dominions and their overflowing treasuries and revenues, you may feel dishearten and doubt that such a people could never be overcome. But my Hindi brothers, if you look in your holy books you will see how many magnificent dynasties have come into being in the land of Hindustan and how they all met their end. Even Ravana and his army of demons were beaten by Raja Ramchandra.

If god brings all these magnificent Kingdoms to an end after a short period, why do you not comprehend that god has sent his hidden help (mujahidin and other Sepoys) to defeat this hundred year old Kingdom of the British, so that this community (British) who addressed your brothers and sisters as black man have now been insulted and humiliated. Realize this and you will lose your fear and apprehension. To run away and turn your back now would be akin to denying Devine help and favors [3]

Though the British confined the great war of 1857 in a narrow perspective of religious fanaticism but the Delhi Urdu Akhbar contradicts with the colonial perspective of the event. However a lot of such primary data preserved in the form of proceeding papers and trial papers in national achieve of India which clearly prove that the war had been in the basis of nationalism.

\section{National movement and contribution of Muslim scholars}

From the day British entered in India the Muslim intellectual always seen playing role against British authority which was based on the ideology of Shah Wali Ullah Dehlowi who for the first time opposed the governing system of British authority and tried to establish a nation which was full of principal of modern nationalism. Shah Waliullah Dehlovi, a profound literary giant and a torchbearer of nationalism, socialism, federalism, Who speaks on behalf of equality, justice, freedom and prosperity of Indian natives irrespective of cast colour and religion long before the event of 1857 [4]. A lot of Indo-Arab

\footnotetext{
3 . Delhi Urdu Akhbar, 14 June 1857. And Mutiny Paper Press list. Sup.Govt. Printing, India, 1921. P.393-398.and Proceedings on the trial of Md B.Shah, King of Delhi, before a Military Commission, upon a charge of rebellion, Ttrason and Murder, Held At Delhi, on the $27^{\text {th }}$ day of January 1858 , and following days. 120-127. ${ }^{4}$.Dehlovi Shah Waliullah, Hujjatullah Al Baligha, Faisal International, New Dalhi, Latest edn. 2007. (Chapter- Babus Siyasath al Madaniya, Chapter- Ebtia Al Rizq also Chapter- Babu Al Rusum Al Sayira Bain Al Nas, Chapter-Akhamatul Irtifaquat wa Islahur Rusum, Chapter- Dabtul Muhim. Chapter- Babul Buyou Al Munhi Anha). and Sayyid Mian Sahab, Ulama-e-Hind ka Shandar
}

scholars influenced by his doctrines and principles which inspired them to assert freedom from government with a non-cooperative stand [5]. I am not going to attempt on detailed biography of Shah Waliullah Dehlovi but in order to point out the British politics of historiography, (That historiography, which bent on approving him the father of the radical Islamic reformer rather than a true torchbearer of Indian Nationalism, socialism and liberalism). I am compelled to throw some fresh light on his philosophy that talk in favour of Indian citizen. His thought of a nation was same as Gandhi, Abul Kalam Azad, Bhallav Bhai Patel, and Baba Sahib Ambedkar. His theory of nation was drowning up in 1731, long before the French revolution which was regarded as the pioneer of the revolutionary movements. It is known to all that French revolution started in 1789. That means, Shah Waliullah Dehlovi taught the theory of a modern nation to his disciples in advance to which the French revaluation had required a half century to reach And Karl Marx's communism had to await one century to be emerged, while the machine age was to start in Europe after nearly 40 years. He provided a simple and easy solution to the burning problems through what the Indian natives had to undergo for 150 years. If his theory would have been followed by all Indians then India would become a free nation before 150 year prior to 1947 . To understand the fact we need to interpret the theories and notions carefully. So these are:

1) Labour is the fundamental cause of wealth. The lion part of national wealth is produced by labourers and farmers so they are the earning faculties of a nation. The main sprite of civilization is the mutual assistance. One could not be the shareholder of the wealth of a country in true sense until he serve for the nation and people. All citizens have equal right to enjoy freedom and prosperities as being an inhabitant of the country without discriminating cast color and creed everyone should be provided the right to justice, security of life and property, they should have the right to protect their honour and religion, culture and traditions. Everyone should have the equality in civil right [6].

1) Gambling and usury system should be cleaned out as they are the main obstructions in the right system of wealth distribution and it cannot guarantee increase in national wealth [7].

\footnotetext{
Madi, ( The Glorious past of Indian Elites) vol-2 first edition 1957 and latest edition-2004, Faisal International, New Dalhi. p. 559.

5. Gail Minault, The Khilafat Movement: religious symbolism and political mobilization in India. Columbia press, New York. Isbn10. 0231050720. 22 august 1982. P.25.

${ }^{6}$. Dehlovi Shah Waliullah, Hujjatullah Al Baligha, Latest edn. 2007.( Chapter, Al-Siyasat-ul-Madaniah, Al-Budoorul Bazighah, Chapter Al-Irtifaq Wa Al-Khair Al-Kaseer). See also Sayyid Mian Sahab, Ulama-e-Hind ka Shandar Madi, ( The Glorious past of Indian Elites) vol-2 first edition 1957 and latest edition-2004, faisal international New Dalhi. p. 412 and 559.)

7. Dehlovi Shah Waliullah, Hujjatullah Al Baligha, New Dalhi, Latest edn. 2007, ( Chapter. Ibtigha-ur-Rizq). see Sayyid Mian Sahab, Ulama-e-Hind ka Shandar Madi, ( The Glorious past of Indian Elites)
} 
2) Mazdoor and peasants and those who provide their intellectual service to the country deserve the wealth of country the most. The development of the worker classes is the indicative of the development of a nation and a system that suppresses such classes is bound to be overturned [8].

3) An authority that imposes unbearable taxations on labours, farmers and craftsman should be considered as the enemy of the nation and they should be deposed [9].

4) A time limit should be granted for the workers so that they could give time to their families and could think about their future, societies and nation [10].

5) Every community and group has their basic right to protect and develop their language and civilization [11].

6) To get food, clothe, house and right to marry and educate their children should be considered as their birth right for the dwellers of a nation. No discrimination should be entertained in the name of cast colour and creed in these affairs [12].

7) Trade is the main root of mutual assistance; so tread should be carried out on the basis of cooperation. Traders are not allowed to breakdown the spirit of cooperation by black marketing. The government is also forbid to hamper the progress growth of business by imposing heavy taxations [13].

8) Those royal system deserves to be perished which interferes authentic circulation of wealth due to extravagance so that the sufferings of the common populace come to

vol-2 first edition 1957 and latest edition-2004, Faisal International New Dalhi. p. 559.

${ }^{8}$. Dehlovi Shah Waliullah, Hujjatullah Al Baligha, New Dalhi, Latest edn. 2007, (Chapter. Ibtigha-ur-Rizq). see Sayyid Mian Sahab, Ulama-e-Hind ka Shandar Madi, ( The Glorious past of Indian Elites) vol-2 first edition 1957 and latest edition-2004, faisal international New Dalhi. p. 559

9 . Dehlovi Shah Waliullah, Hujjatullah Al Baligha, New Dalhi, Latest edn. 2007, (chapter. Ibtigha-ur-Rizq). see Sayyid Mian Sahab, Ulama-e-Hind ka Shandar Madi, ( The Glorious past of Indian Elites) vol-2 first edition 1957 and latest edition-2004, faisal international New Dalhi. p. 559.

${ }^{10}$. Dehlovi Shah Waliullah, Hujjatullah Al Baligha, Faisal International, New Dalhi, Latest edn. 2007, (chapter.Isabat-alIrtifaqat, Ihatur-Rusoom, Zabt-ul-Mubham). see Sayyid Mian Sahab, Ulama-e-Hind ka Shandar Madi, ( The Glorious past of Indian Elites) vol-2 first edition 1957 and latest edition-2004, faisal international New Dalhi. p. 559

${ }^{11}$. Dehlovi Shah Waliullah, Hujjatullah Al Baligha, , New Dalhi, Latest edn. 2007.Also, M.Muhammad Miyan, Silk Letter movement. P.35

12. Sayyid Mian Sahab, Ulama-e-Hind ka Shandar Madi, ( The Glorious past of Indian Elites) vol-2 first edition 1957 and latest edition-2004, faisal international New Dalhi. p. 559.

${ }^{13}$. Dehlovi Shah Waliullah, Hujjatullah Al Baligha, (Chapter AlIrtifaq and Al- Buyoo Al Manhi Anha), Faisal International, New Dalhi, Latest edn. 2007. an end and they are provided equal right to live [14].

9) A ruling authority of a country should administrate the country as to be a manager of an endowment. So he could not use public wealth as much as he wish but his salary should have confined as to that of a common subject needs to lead his life[15].

10) To get these rights it is necessary to form an independent state which is free in their affairs. It should have such power to protect its sovereignty. It will not be allowed to attack any unit of particular religion or particular civilization [16].

The then Urdu and Arabic resources which had still not been accessed by English readers are the witness of many untold facts about the freedom movements. Shah Waliullah formed his revolutionary groups on his own ideology. His ideologies played an important antagonistic rule against the British policies in Indian subcontinent. Each and every points of his preaching were somehow confronting the illegal administration of British India. in one hand his followers preaches jihad against British for their fundamental right and on the other hand they began to get down into the intellectual counter attack against the Christian missionary groups who planned to change the old-age Ganga Jamuna Thezib by converting Indian to Christianity. Those Indo-Arab scholars who spoke against Christian missionaries were noted in English history as religious fanatics and those who stood for the rights of Indian people were called as looters, militants, plunderers or mutinous groups in their history. This kind of politics are clearly visible in colonial historiographies because when we go through them, we could able to see that the British historian did not assemble all these issues in one single point and interpreted them separately whereas all those initiatives were taken for a single cause. And that was to free India from British oppressions.

\section{Contribution of Muslim elites to the unity and brotherhood among the natives}

Though many of the colonial historians interpreted this national war merely as the religious movement or an uprising of some militant Sepoys but the untouched documents from the national archive of India together with the Mutiny papers stored therein, compelled anyone to attribute this movement as a national awakening of Indian people through their

\footnotetext{
14. Dehlovi Shah Waliullah, Hujjatullah Al Baligha, (Chapter Ibtigha Al Rizq). Faisal International, New Dalhi, Latest edn. 2007.

15. (Dehlovi Shah Waliullah, Hujjatullah Al Baligha, New Dalhi,

Latest edn. 2007 Izalatul Khifa, vol 2. see Sayyid Mian Sahab,

Ulama-e-Hind ka Shandar Madi, ( The Glorious past of Indian Elites) vol-2 first edition 1957 and latest edition-2004, faisal international New Dalhi. p. 559.

16. Qasimi Muhammadullah, Silken letters movement.Shaikhul Hind Academy, Darul Uloom Deoband, Saharanpur in association with Manak Publication Pvt Ltd, New Delhi 2012. P. 35.
} 
religious consciousness. Unity between Hindu and Muslim community against British rule was one of the greatest example of Indian nationalism. Each community considered others as their brothers on the basis of nationality and discriminated British considering them as an alien race who ruled them oppressively. Even the Sepoys of Hindu communities did not hesitate to use Islamic language in their letters and applications to the royal administrations. The petitions of General Sudher and General Hira Singh to Mirza Mughals office testified that very well. We can see that Both Hindu commanders were describing the uprising as Jihad and addressing the British as Kafir (infidel) in their petitions [17]. Later used deliberately by Henry Miers Elliot, and John Dowson [18]. In their history books to create dichotomy between Hindu and Muslim so that the unity of both communities would have tore down. Even during the uprising British tried to break the unity of Indian natives. They tried to lubricate the increasing voice of Indian people with Islamic flavor. There are references from Mutiny papers where the fragrances of British dichotomous policies had been turned up. A rumor had been circulated that the Entire Hindu communities were alliance with the British. There is also a petition from an old Begam who demanded some Muslim soldiers from Zafar in order to protect him from the oppression of Hindus belong to Sita Ram bazaar. She proclaimed: Dear relative she addresses as " to protect me from evil and corruption of the Hindus...........God forbid that the Hundas might by trickery introduce some spy into the army and so have my house plundered and looted [19]."

For this false alarm many Hindu became anxious and disturbed. Soon Maulanaa Mohammad Baqr got down in indulging the Hindu community saying them not to lose hearts. In his columns, there was a calling to his Hindu readers as well as the citizens of India to rise together against their common foe and maintain their unity against British. He compared the Englishman to Ravana of their holly book Ramayana. In Delhi Urdu Akhbar of $14^{\text {th }}$ July he wrote that though the English were one of the powerful rulers of the world and they had the capacity to roll the world as they wish but nothing was permanent in this world. He farther quoted reference from Ramayana and said that the Hindu brothers should take lesson from their glorious past. This country witnessed a lot of such powerful authorities but God brings all these Mightiest dynasties to an end after a short period. The history of our country is full of such incidents. Once King Rabana had been the most powerful ruler of the world and

\footnotetext{
${ }^{17}$. NAI, Mutiny Papers, collection 57, no. 484, 12 September 1857. (nationalarchives.nic.in, 08, 11, 2018) (www.abhilekh-pata.in 07.09.2018)

${ }^{18}$. Eliot and Dowsans History of India as told by their own historians. London 1858

${ }^{19}$. NAI, Mutiny Papers, Collection 100, no. 179.

(nationalarchives.nic.in, 08, 11, 2018 ) (www.abhilekh-pata.in 07.09.2018)
}

more prosperous then the British but Pravu Ram Chandra destroyed him and ruined his all pride. He also mentioned that this rapacious white skinned Englishmen used to call our brothers and sisters "black Man". And humiliated and oppressed the Indian native so all should unite against the common British enemy and not to lose their heart, god will bless them soon [20].

One of the most powerful weapons of Mughal court was the Hindu Muslim Unity. The Jihadi Groups and the Hindu soldiers lived together with love and affections as Sir Sayid Ahmed said that they always considered each other as brother and the burning example of such unity is the petition of the Hindu Sepoy who refers the uprising as Jihad and the kafir (unbeliever) as the British.

For British, Initially the war confined with only the Rebel Sepoy but as the time proceeded the outbreak took the shape of a widespread civil war. Day by day the Mughal troops were reinforced by thousand of civilian mujahidin and the Sepoys coming from outside Delhi. A lot of Sepoys from Ambala, Jalandhar, Haryana, Nasirabad and Bangal gathered in Delhi. To add to the British woes, a large number of armed civilian and freelance Mujahidin groups gathered within the city wall who believed India to be the peaceful country and it was their duty to free their country from the rapacity of Christian Kafir.

As soon as Jihadi arrived at Delhi they set their camp in the courtyard of Delhi Zamma Masjid and of a little distance another Jihadi Groups from Rajastan took shelter in Zinatul Masazid located at riverside. Initially both Sepoys and Mujahidin fought side by side for some misunderstanding but later they could understand that both groups had uniform mission i.e to free India from British oppression ${ }^{21}$. The Mujahidin groups proclaimed the Jihad against British and began to inflame the Muslim community against British. They gathered the city people and preached that it is necessary for all Muslim to stand against British as it is their religious duty to save their motherland and their faith from the evil powers. One revolutionary pamphlet from the mujahidin groups which clearly emphasized on the Hindu Muslim Unity and call the Hindu community to join the war:

The Hindus should join the Emperor with a view to defending their religion, and should solemnly pledge

\footnotetext{
20. Delhi Urdu Akhbar, $14^{\text {th }}$ July 1857. And Mutiny Paper Press list. Sup.Govt. Printing, India, 1921. P.393-398. and Proceedings on the trial of Md B.S, King of Delhi, before a Military Commission, upon a charge of rebellion, Ttrason and Murder, Held At Delhi, on the $27^{\text {th }}$ day of January 1858, and following days. 120-127. (nationalarchives.nic.in, 08, 11, 2018 ) (www.abhilekh-pata.in 07.09.2018)

${ }^{21}$. NAI, Mutiny Papers, Coll, 67. 77, $27^{\text {th }}$ July 1857 for Zinat U1 Masajid; and coll. 15, file 1 for Jama Masjid.

(nationalarchives.nic.in, 08, 11, 2018 ) (www.abhilekh-pata.in 07.09.2018)
} 
themselves; the Hindus and Mahomedans, as brethren to each other, should also butcher the English, in as much as the Mahommadan Kings protected the lives and property of the Hindus with their children in the same manner as they protected those of the Mahommadans, and all the Hindus with heart and soul were obedient and loyal to the Mahommadan Kings... the Hindus will remain steadfast to their religions, while we also retain ours, aid and protection will be offered by us to each other[22].

\section{Contribution of Indo-Arab Scholars in building unity among the Indian people}

The Indo-Arab scholars were always seen active to unite the Indian people irrespective of all religions against British. Among the Mujahidin Groups the most intellectual and experienced battle-hardened soldier was Maulavi Sarfaraz Ali who was a profound Indo-Arab scholar and a literary giant of his period. He was a scholar of Mufti Sadruddin Azurda, the leading literary personality. Maulavi Sarfaraz became Graduate from Darul-Baqa, an institute of Delhi situated to the south of Jama Masjid. He had profound knowledge in both Arabic and Urdu language. More then so he was a master of algebra and geometry. Sir Sayid Ahmed khan praised him adding, he was one of the brightest jewels in Delhi's intellectual crown [23]. He was a true politician and had a great attachment with Mughal Court and Delhi city. From the very beginning of uprising he played the most vigorous stratagems against British rule. He used both his pan and talwar against British. He was one of the soundest figures among those Ulamas who preached Jihad against British days prior to the revolt of 1857 . As soon as the Sepoys entered in Delhi this Maulavi stood with them and on $1^{\text {st }}$ may arranged a mass gathering at Shahjahanpur and preached open Jihad against British. He proclaimed addressing the widespread audience: ... our religion is now in danger as well as we lost our sovereignty over our land, we now bowed in subjection to the impure kafir (British), shall we surrender the inalienable privileges which we received from the Prophet P.B.U.H [24]. Bakht Khan was a leader who had been regarded as one of the most lethal rebel among all rebels. He was singled out by Colonel George Bourchier for praise as one of the profound master of Persian and Arabic literature, an intelligent character and a furious horseman. Colonel George himself was one of his students who learnt Persian language from him [25].

\footnotetext{
22. Cited in Rudrangshu Mukherjee, Auadh in Revolt 1857-8 A study of popular Resistance, New Delhi, 1984, p. 153.

23. Khan Sir Sayyid Ahmad, Asar Us Sanadid, Delhi, 1990 vol.2. and Swapna Liddle's excellent essay on Azurda in Margrit Pernau (ed.) Delhi college, New Delhi, 2006.

${ }^{24}$. William Dalrymple, The last Mughal, Panguin Books India, 2007 p. 285 .

25. Bourchier Colonel Geoge, Eight Months Campaign Against the Bengal sepoy Army During the Mutiny of 1857, London, 1858. p.44
}

Bakht Khan came to Delhi as the rebel commander and reputed administrator of the Bareily rebel military force. He had already earn the credential as a damning army man, now going to be join with his spiritual guide Maulavi Sarfaraz Ali who was already known as the Imam of the Mujahidin. Some account denoted that it was Maulavi Sarfarz Ali who motivated Bhakt khan to fight against British. As soon as Bakht Khan arrived at Delhi he along with four thousand Jihadi soldiers who came with his rebel army from Beraly came under Maulavis revolutionary banner. All of the Jihadis and rebel army were waiting for just an order of Maulavi Sarfaraz Ali. Wiliam Dalrymple admired him saying: if anyone could unite the Sepoys, the Jihadis and the Delhi elite, here potentially were the two men i.e Maulavi Sarfaraz Ali and his disciple Bakht Khan to do it [26]. Hakim Ahsanullah Khan who was the prime minister of Zafar wrote that When Bakht Khan and his spiritual mentor Maulavi Sarfaraz Ali entered the place in order to meet Zafar; he was present at the court so as eye witness he noted all the conversation. According to his account Bakht Khan and Maulavi Sarfarz Ali together with 250 selected officers reached at Mughal Court and Bakht Khan rushed into the Diwan-e-Khas and salaamed the King Zafar and then started their conversation. After a long discussion Bakht Khan said, I come to know that the princes were given the authority to run the jurisdiction over the soldiers. But they are less experienced about the strategies and maneuver of British militaries. Give the power to me. I will train them and make them ready for the fight. The King replied "The princes were appointed according to the suggestion of military officers [27]. Zafar was well-known about the bravery of Bakht Khan and could rely on his ability. So he soon appointed Bakht khan as the commander in chief of all rebels replacing Prince Mirza Mughal, the former Commander-in-Chief and then Mirza Mughal was installed as the Adjutant General who was the supreme authority of the administration [28]. Soon after his appointment, having supreme authority over all the mutinous groups, he made an energetic effort to unite all the regiments and systematized the arrangement of soldiers in a proper war platoons. He made several flanking operations and sent his armies dividing them in several platoons alongside the river Yamuna on 3 July so that the British could not pass a single day without having at least one confrontment [29].

On the other hand he was busy on preparing other groups for next month. The plan was to send a large group by Ajmiri Gate who will proceed towards

\footnotetext{
26. Dalrymple Wiliam. The last Mughal, Penguin Books India, 2007. 285.

27. Darlimpal William, The Last Mughal, Panguin Books, India., 2007. p. 286.

${ }^{28}$. Metcalfe, C.T, Two Native Narratives of the Mutiny in Delhi. (Munshi Jiwan Lal) London, 1898, pp.134, 167.

${ }^{29}$. NAI, Mutiny Papers, Collection 15, no.19, early July 1857. (nationalarchives.nic.in, 08, 11, 2018) (www.abhilekh-pata.in 07.09.2018)
} 
Yamuna River to cordon the British force from both side. When Zafar was informed about this plan he said "Go, May God protect you, Show your loyalty by attacking the English, destroy them and return victorious [30].

According to the plan Bakht Khan with huge military forces started March towards Najafgarh in order to cross the river Yamuna from south. The roads became oozy due to the heavy rainfall. It became difficult to forward the stapes due to the slippery dank road. When they reached to the bridge they saw it was already worn out by the order of General Wilson. Bakht Khan never loses heart and ordered to repair the bridge as soon as possible. It required 24 hours and finely they repaired it. When the troops began to cross, the bridge fall down and sank a number of Sepoys. The remaining soldiers were tired and starving for several days. They all damp and wet due to the rain fall. The water surface increased above their knees [31]. On the other side the British through their field glasses watched all the movement of the Sepoys. Charles Griffiths noted: there were seen from the ridge for hours trooping out of the Lahore and Ajmir Gates and proceeding to our right rear [32]. As soon as General Wilson received the massage he calls upon his younger brother John Nicholson and ordered to get ready for another storm. John Nicholson along with Charles Griffiths, Edward Vibart and Theo Metcalfe prepared their platoons at once. And set out for counter attack. The British troops preceded towards the canal, 3 kilo miters north of Najafgarh. And attack them but unfortunately the Sepoy who came here with restless journey, starving for several days now fall asleep [33].

The Bakht Khans military troops got up suddenly and defend the sudden attack. But British covered them from all side and began to shoot so rapidly as if the door of hell opened to the earth. As the Sepoys had been unaware of such improbable attack, they could not stand against. As a result the British captured their camp and killed much of the Sepoys. Hence the British continuously proceed towards the city palace and began to capture one after another camp. The restless fairing was round after round constantly at work for twenty four hours. Charles Griffiths wrote: Day and night salvos of artillery were heard, roll following roll in endless succession [34].

Soon Mirza Mughal passed an order to the natives irrespective of cast colour, creed and religion to come out from their houses and protect the country from British tyranny. The order was proclaimed on $6^{\text {th }}$

\footnotetext{
${ }^{30}$. Metcalfe, C.T, Two Native Narratives of the Mutiny in Delhi.( Munshi Jiwan Lal) London, 1898, p.206.

31. Darlimpal William, The Last Mughal, Panguin Books, India., 2007. p. 330

${ }^{32}$. Griffiths, C.J, The siege of Delhi, London 1910. p.123.

33. Metcalfe, C.T, Two Native Narratives of the Mutiny in Delhi.( Munshi Jiwan Lal) London, 1898, pp 207-208.

${ }^{34}$. Griffiths, C.J, The siege of Delhi, London 1910. p.147.
}

September, by beating drum throughout the Delhi city [35] and ready his soldiers and common man poured in Delhi as mujahidin rebel and fought continually and a lot of Ando-Arab scholars and leaders of rebel groups sacrificed their live and wealth for the sake of motherland till the end of war.

\section{Downfall of great Mughal and the dark age of Indian slavery}

On $20^{\text {th }}$ September the British captured the palace but unfortunately they could not captured Zafar as Zafar had been resided for some days at his forefathers tomb, the great Humayun's Tomb and pray for the rebel soldiers who were fighting day and night for save their motherland. He desired to lead the rebel force in the battle field but It was hakim Ahsanulla khan who suggest him not to go outside as he was too week and not in a condition to lead the expedition. The street fighting between English and native were still continued because the native did not lose heart as they knew that their King is still alive and had still adorning the throne of Hindustan.

Hodson was one of the most intelligent and foresighted officer. He knows well that until the British Capture the King the Indian masses would keep fighting for their Emperor so he rushed to Wilson in order to seek permission for an expedition to capture Zafar. According to him "victory would be incomplete if the King and his male relatives were allowed to remain at large. Wilson gave permission with a condition that Hodson would deal the matter personally and whole matter would be run at his own risk [36]. On $20^{\text {th }}$ September Hodson went to capture Zafar but they had to face a horrible confrontation with Jihadis and finally captured Zafar who was then eighty years old man and suffering from various disease. Even he could not walk without any support. In a visiting W. $\mathrm{H}$. Russell expressed his astonishment that a man with dim wandering eye and a pall face with toothless gum who dare to worn out the world most powerful English authority. But the British cruelty now crossed its limits. They did not hesitated to call him pig and pull his beard, forcing him to stand up and Salam and kept him like a beast in a cage [37].

After capturing the Mughal Monarch the siege of Delhi was doubtlessly accomplished for Englishman but for the Indian people it was the starting of humiliation and woeful condition. In the morning order

\footnotetext{
35. Proceedings on the trial of Mouhammad Bahadur Shah, Titular King of Delhi, before a Military Commission, upon a charge of Rebellion, Treason and Murder, held at Dehi, on the $27^{\text {th }}$ Day of January 1858, and following days, London, 1859. p. 142. (nationalarchives.nic.in, 08, 11, 2018 ) (www.abhilekh-pata.in 07.09.2018)

${ }^{36}$. Hodson, Twelve years of soldiers life in India. London. 1859, p. 300

${ }^{37}$. Campbell Sir George, memoirs of my Indian career, London 1893, Vol 1. Ireland, William. W., A history of the siege of Delhi, Edinburgh, 1861. pp.307-8.
} 
was given to clean the city. The English troops spread throughout the city and shoot everybody whom the saw anywhere in the city. They spread so terror that each and everyone tried to escape the city. A group of 40 people had been caught during their march and dragged them to the bank of Yamuna and lined them up there and shoot them. Most of them were the intellectual figures of the Delhi city who according to Zahir Dehlavi had been the literary jewels of Delhi and unparallel talent of their own time. Zahir introduced them as: Miyan Amir Panja-Kash one of the greatest calligraphers of world. Another one is Maulavi Imam Bakhsh Sahib who was a profound poet who had been praiseworthy for his unique creation in the art of poetry. Mir Niyaz Ali who was one of the talented story tellers Delhi ever produced. Along with these jewels of city, other well-known people were shoot death and threw their dead body in the river. Zahir described the woe and grievous mourning of the woman who sow their husband and children's painful death trial in front of their eyes. They could not bear the pain and jumped along with their children from the wall of the city and committed suicide. Zahir Wrote, "For months afterwards, all the wells of Kucha Chelan were stacked with dead bodies. My pen refuses to describe this further [38].

Infect the English began to capture and kill all those people who had any direct or indirect connection with Zafar and his princes. As the British troops proceeded through the streets they used to loot the houses. The unlucky dwellers had blown by gunshot or cut down and lucky fellows were began to flee from the city out of terror. Among those lucky young man was Maulavi Hussain Azad who was a profound poet of his age who wrote several poetries to inspire and motivate the rebel soldiers to proceed against British. In an evening Azad was staying in his house with his family and a one year old cute baby girl when the British troops suddenly entered his house. Azad wrote the world turned black before my eyes. He then left every think in his house and picked only the packet of Zauq's unpublished Ghazals and Poetry and left the house with his family. He wrote: I left the house abandoning a well- furnished home, with twenty-two half dead souls. During his escape a bullet from the cruel gun of the Englishman struck Azads year old baby daughter and she fall asleep for forever [39]. On the other hand his father Maulavi Muhammad Baqr who had been arrested on or around $15^{\text {th }}$ September was now hanged. A profound literary giant and a true son of motherland was sacrificed his life so silently that he had never been recognized for his devotion to this beloved country so Azad left Delhi and wandering all around the country caring his masters Ghazals all the way and finally in

\footnotetext{
${ }^{38}$. Zahir Dehlovi, Dastan i-Ghadr: An eye witnessed account of the 1857 uprising Lahore, 1955p. 128.

39. Farrukhi, Aslam, Muhammad Husian Azad Vol 1, Karachi, 1965. p. $100-115$.
}

1861 he stayed in Lahore and spent his life as a ordinary postmen in a small post office [40].

Following morning just after capturing the King of Hindustan, the British authority issued a warrant to catch all the princes who were the main mastermind of the horrible revolt in Delhi. Hodson along with his force went to capture the prices and after a long effort he successes in his mission and captured Mirza Mughal, Khizr Sultan and Mirza Abu Bakr whose command had let the Englishmen fail to stand on their legs out of fair and terror. Hodson himself wrote that they had able to coin an indelible terror in the heart of Englishman by their gigantic violence during entire revolt. Even Wilson who was the doughtiest officer of British could not stand on his legs, wrote Hodson ${ }^{41}$. However when they came across the Kotwali, Hodson ordered his soldiers to line the princes up on the street. He holds his colt pistol and shot them dead with cool blood. One after another the group of patriots falls down on the ground. Hodson picked their bejeweled swords and signet rings up and left them out naked beside the street near the Kotwali. In the afternoon Charles Griffiths went to visit the dead bodies at Kotwali. He wrote: I saw them that 2 same afternoon; nor can it be said that I or others who viewed the lifeless remains felt any pity in our hearts for the wretches on who had fallen a most righteous retribution for their crimes. The eldest Mirza Mughal was a strong well-knit man in the prime of life, the next Khizr Sultan somewhat younger, while the third Abu Bakr was quite a young of not more than twenty years of age. Each of the princes had two small bullet-holes over the region of the heart, the flesh singed by gunpowder as the shots were fired close. The bodies remained for three days and were then buried in dishonoured graves [42]. After their burial another remaining sons of King Zafar were captured, trialed, and hanged brutally by the British so that any young members of the house of Timur would never be alive to raise voice against the rapacity and cruelty of British authority. After the death of the princes the city became a master less property. No one remain in the city to protect the Englishman from looting murdering and hanging the innocent natives of their motherland. An estimation of 50, 000 hanged mutineers by Lord Canning had been putted in his latter to Queen Victoria on $25^{\text {th }}$ September that: Violent rancor of a very large proportion of the English community against every native Indian of every class. There is a rabid and indiscriminate vindictiveness abroad, even amongst many who ought to set a better example, which is impossible to contemplate without something like a

\footnotetext{
${ }^{40}$. Frances W. Pritchett, Nets of Awareness. Urdu poetry and its critics, Berkeley and Los Angeles, 1994, pp. 25-6. Also. Farrukhi, Muhammad Hussain Azad, Vol.1, Karachi, 1965. pp. 109-10.

${ }^{41}$. Major W.S.R. Hodson, twelve years of soldiers life in India. London. 1859, p. 296.

${ }^{42}$. Charls John Griffiths, the siege of Delhi, London, 1910, pp. 204 205.
} 
feeling of shame for one's fellow countrymen. Not one man in ten seems to think that the hanging and shooting of 40 or 50, 000 beside other rebels can be otherwise than practicable and right [43]. However after having trail, all the fellows related to Mughal court and Mughal house had been either hanged or put into prison. By the end of January 1858 Zafar was remain only the single member of great Taimur House who lied in his own palace as a prisoner waiting for his trail. Mughal court was laid barren of nobleman, poet, philosophers and literary scholars for the first time after long 400 years. Zafar lost his everything. He remembered day and night the poor condition of his motherland. His land is now at the hand of rapacious race. His capital was now a desert rather than a beautiful city. Almost all the friends and relatives were killed. How can he forget them? How can he bring them back? Every knowing souls, every close disciples, every bosom friends, teachers, students, lovers were gone far away from this terrestrial world who would never back again. Now he was only one of the living members of his house who was now at the door stair of ethereal journey. He wiped on his misfortune that if he were to die no one in the world would be left to mourn for him or remember him and after his death his country would be a lampless land. The heartless English race would ruin the land which was ornamented with glory of humanity and brotherhoods by his ancestors. He wiped for his motherland day and night. In silence his eyes swamp with tears when he remember his own composite verses which came out aversely from his trembling lips:

"O Zafar, we are going to take London shortly, It is not far [44]."

On 27 January the trail of Zafar took place. Major Harriott who already had hanged many of Zafar's court noblemen and family by his prosecution now took the case of Zafar under his legal proceedings. Zafar was then too weak and unable to walk without support.

What would be the outcome of the trial where the Judges and the advocate were Englishmen in an English court in Hindustan? The evidence was furnished from the manuscripts collected from court and office of Mirza Mughal. Major Harriott the prosecutor argued that all the evidence found from Mughal court proved Zafar as the mastermind of the great revolt against English Authority. Harriott also argued that Zafar was the main player behind the international Muslim conspiracy against British. He said that the conspiracy that spread to the entire world from Constantinople to Middle East was raised from the bastion of red fort. The trail was going on without validating the major question that whether a foreign company had the legitimacy to precede the trial against

\footnotetext{
43. Michael Maclagan, 'Clemency' Canning, London, 1962, p. 98.

44. DCO Archives, new Delhi, Mutiny Papers, file 63, 1857. (www.abhilekh-pata.in 07.09.2018)
}

a King whose ancestors gave them permission only to do business and act as the revenue collector of his territory accepting his supremacy. Zafars Ancestors came to India as ruler but British did no enter this land with the same readiness. They entered India as an agent of a foreign crown who submits themselves in the feet of Mughal King as petty servant. If we see all this things than we must accept that the trial was nothing but an evil treachery of Englishman to humiliate the Indian sovereignty and loot India without any disturbances. However Major Harriott emphasized mainly on the Muhammadan conspiracy behind the dreadful mutiny against British and proved that Zafar was the evil genius behind the revolt of 1857 . He said in front of the judges that:

The conspiracy, forms the very commencement, was not confined to the Sepoys, and did not even originate with them, but had its ramifications throughout the palace and city. Zafar was the leading chief of the rebels in Delhi. .... Dead to every feeling that falls honorably on the heart of man, this shriveled impersonation of malignity must have formed on inapt centerpiece to the group of ruffians that surrounded him we see how early and how deeply the Muslim priesthood interested and engaged themselves in this matter, and how completely and exclusively Mahommedan in character was this conspiracy...The original mover, the head and front of the undertaking or but the consenting tool.. Many persons, I believe, will incline to the latter. The known restless spirit of Mahommadan fanaticism has been the first aggressor, the vindictive intolerance of that peculiar faith has been struggling for mastery and seditious conspiracy has been its means, the prisoner (Zafar) its active accomplice and every possible crime the frightful result. The bitter zeal of Mahommedanism meets us everywhere, which was perfectly demonic in its actions [45].

However the trial continued for two months and the court martial took place for the last time on $9^{\text {th }}$ march. Zafar was considered as the guilty of all activities that happened during the outbreak of 1857 and was sentenced to be exiled to Andaman Island or similar another place far away from the Capital of India. Finely after seventh month towards the end of September 1858 the British authority decided to exile Zafar to Rangoon and at 4 A.M in the morning of $7^{\text {th }}$ October 1958 the Great Mughal Emperor had been sent out from Delhi to live the rest of his life as a prisoner in a barren fort situated in Rangoon. this exiling ceremony was carried on with a greater secrecy because till now the citizen of India assumed Zafar as their Supreme authority so the British was in a suspicion that the news of Zafar's exaltation could create another challenging storm for British empire.

\footnotetext{
45. Proceedings on the trial of Muhammad Bahadur Shah, Titular King of Delhi, before a Military Commission, upon a charge of Rebellion, Treason and Murder, held at Delhi, on the $27^{\text {th }}$ Day of January 1858 and following days London, 1859 .pp.151-3.
} 
Matilda Saunders wrote to her mother in low that the exaltation was carried out secretly as no one of the native aware of the incident. She said. No one crowded to see them go; it was completely still and quiet at the early hour.

On $8^{\text {th }}$ December the ship Magara set out for Myanmer and the ship sailed across the open ocean and entered into the Rangoon River. When the ship stopped at the Port of Rangoon River, as Ommaney stated a huge number of masses gathered in order to see the Great Mughal King of India, but in Rangoon the Commissioner, Major Phayre did not arrange any proper housing for the prisoners. And let them stay in a negligible confined house having two small rooms. Ommaney wrote: At present two little rooms neither as large as any in the house at Delhi .....the prisoners now have scarcely any comfort. Later the prisoners were shifted to another containment which is consist of four rooms each 16 feet square which is too small to cover all the prisoners. Reported Zafars new jailer, Captain Nelson Davies, One small room was allotted for King and his wives and another one is for Prince Jawan Bakht and his wife, third was occupied by Begum Zinat Mahal and fourth was for Shah Abbas and his mother. Two bathroom which were shared by all the inhabitants of the house and for attendance barandhah was the only place to spent their day and night and a small space between or among the rooms was assumed as the kitchen and that's the enough facilities for the Mightiest King of Hindustan. Zafar spent his life with great humiliation as if he was a beast in a cage. He was put on show to visitors. Many English went to see him. An Englishmen Henry Layard the former MP for Aylesbury went to visit Zafar. He stated the miserable condition of Great Mughal King and expressed his sympathy for old men who had been humiliated by cruel English race. He said: I will not give any opinion as to whether the manner we are treating him is worthy of a great nation. I saw that broken-down old man not in a room but in a miserable hole of his palace - lying on a bedstead with nothing to cover him but a miserable tattered coverlet. As I am held him, so remembrance of his former greatness seemed to rise in his mind. He rose with difficulty from his couch; showed me his arms which were eaten into by disease and by flies- partly from want of water and he said in a lamentable voice that he had not enough to eat. Is that way, as Christians, we ought to treat a King? I saw his women too, all huddled up in a corner with their children; and I was told that all was allowed for their support was $16 \mathrm{~s}$ a day! Is that not punishment enough for one that has occupied a throne ${ }^{46}$. He was even not provided the pan and paper so he used to write poetry on the wall of prison. William Howard Russell after his visiting wrote: Some heard him quoting verses of his own composition, writing poetry on a wall with a burned stick [47].

He spent day and night with great humiliation though he never forgot to recite the praise poetry of motherland where he spent his beautiful days and now he had no hope to return back there. Zafar became weak then weaker day by day lamenting all that happened in his life. He lost his sons, his family, his people who respect him and love him as a true guardian and well wisher, his palace, his hereditary throne, Sitting on which, his ancestors escorted the four flashpoints of great Hindustan since 1526 which was now on the hand of some alien race who had no soft corner for this land. They bent on destroying all the prosperities that his ancestor brought for this land. And now it was his time to sacrifice life and wealth to save the dignity and honour of this adorable land. He spent 4 years lamenting all misfortune that had descended to him and his motherland till he became the bed ridden old sick men who was counting munities and seconds of his sinking life. His most nearest attendants who also accompanied with his life journey were surrounding him to comfort their master in his last journey. One day evening on $7^{\text {th }}$ November 1862 Ahmed beg one of his most faithful attendance rush off from the prison enclosure and informed the escort that their Master and the last of great Mughal crown, the King of Hindustan Bahadur Shah Zafar had left this world few hours earlier. As soon as they heard this news they went to captain H.N. Davies and murmured on his ear that the State Prisoner was died. According to the document of National Archive of India and the latter of H.N. Davies who was then the in charge General of State prison of Rangoon, the British Authority had left no stone unturned to hide the news of woeful death and the wonderful credential of Last King of Hindustan, Bahadur Shah Zafar. They buried him in an undistinguished place backside the prison enclosure so that no one could trace the burial place of the Great Patriot of Hindustan Bahadur Shah Zafar. A week later after his burial H.N. Davies wrote to London saying that:

Have since visited the remaining state prisoners- the very scum of the reduced Asiatic harem; found all correct. None of the family appears much affected by the death of the bed-ridden old man. His death was evidently due to pure decrepitude and paralysis in the region of the throat. He expired at 5 o clock on the morning of the funeral. The death of the ex-King may be said to have had no effect on the Mahomedan part of the populace of Rangoon, except perhaps for a few fanatics who watch and pray for the final triumph of Islam. A bamboo fence surrounds the grave for some considerable distance, and by the time the fence is worn out, the grass will again have properly covered the spot and no vestige will remain to distinguish

\footnotetext{
46. Quoted in Ball, Charles, History of the Indian Mutiny, London 1858-9, vol-2 pp.179.
}

47. Russell W. H., My Diary in India, London, 1860 vol. 1, p. 60. 
where the last of Great Mughals rests[48]. Thus the great patriot and a true torch bearer of modern Indian literature and the last lamp of Timure Dynasty left all the desirable things behind, departed from his beloved Delhi and respond the call of motherland and died in exile as a state prisoner in Rangoon on Friday, $7^{\text {th }}$ November 1862. However after his death the rule of Mughal dynasty declined forever and the union Jake occupied the highest vault of read fort and Indian citizen were reduced to the slavery of British crown entirely till 1947.

\section{Conclusion}

From the day immemorial India has been a secular nation. Thousand of community irrespective of cast, color, and creed doweled in this Holy place and represent a unique example of love, respect, humanity and brotherhood in the history of world. Unity has been the main strength of this nation. Our ancestor proved that practically by their action. The freedom movement fought by them was nothing but the result of unity and brotherhood. They altogether irrespective of cast, color, creed and religion fought against British. And that unity was the main head ach and unturned hindrance for the British. The British were naturally very clever and far sighted ruler. They could easily comprehend that unless they could break down the unity of the harmonized multi-community Indians, they could not rule the large Indian subcontinent. So they adopted the policy of divide and rule. Native against the native was the main weapon of British. Thus the British inseminated the seed of communalism among the masses of India. If we observe the history of India written by British writers then we can comprehended that the same policy was being applied by them because they knew that if the Indians remain united and work together irrespective of cast, color and creed then in future India would become the no-1 powerful nation in the world which they never wanted to be. It is a sorrowful matter that some so called Indian writers too without observing the matter followed the foot print of those British writers. As a result the contributions of some communities along with Muslims were underestimated and became sublimed thereby not highlighted as they deserved. This is the reason that in present scenario some community demands that they did highest contribution to the freedom movement which leads to a great conflict among the communities. But the actual matter is not like that rather all communities irrespective of cast, color, creed and religion equally contributed and laid their lives for the sake of motherland and handover the country to their next generation so that they could work together avoiding all kind of diversity and lead the country to the highest position of honor. So we the new generation should not divide the great warriors in the name of cast, color, creed and community rather should follow the

48 . N.A.I, Foreign Department, Political, November 1862, p. 20462.cited Dalrimopal William, The Last Mughal, Panguin Books, 2007.p. 2. foot print of those great personalities and work together as the sons of a mother to fulfill the dream what our ancestor dreamt for our nation.

\section{References}

1. Michael Maclagan, Clemency Canning ,Charles John 1st Earl Canning, Governor-General and Viceroy of India, 1856-1862 London, Macmillan, new York, St. Martin's Press, 1962,

2. Dalrymple Willliam, The Last Mughal ,Penguin Books India, 2006.

3. Coopland. R.M., A Lady's Escape from Gwalior and life in the fort of Agra during the Mutinies of 1857, London, Smith, Elder, and Co. 65 Cornhill 1859.

4. Delhi Gazette Extra, issued 10 December 1857.

5. Madani. Husain Ahmad, Naqsh-e-Hayat (نقش حيات) written in jail in 1944. Published, Darul Eshaat Urdu Bazar Karachi-1. Phone no-213768. Vol1,Vol-2.

6. Pritchett, nets of awareness.

7. Dehlovi,Zahir, Dastan-e-Gadhr(داستان غد ر): Ya Taraze Zaheeri, Lahore, 1955.

8. Khairi, Rashidul Dilli ki Akhiri Bahar, ed. Zamir Hussain, Delhi, 1991.

9. C.M. Nnaim in his Essay on Sahbai in Margrit Pernau (ed.)Delhi college, New Dalhi, 2006.

10. DCO Archive, Mutiny Papers, file number-5, Box number-1，， $2^{\text {nd }}$ October 1857, no.279, C.B. Thornhill to G.I. Hansey.

11. Khairabadi, Fadlul Haque, Al Sauratul Hindiya (الهندية الثورة).

12. Qasimi, Muhammadullah, Silken Letters Movement, Manak Publications pvt ltd, new Delhi2012.

13. Rawlat committee report.

14. Proceedings on the trial of Mouhammad Bahadur Shah, Titular King of Delhi, before a Military Commission, upon a charge of Rebellion, Treason and Murder, held at Dehi, on the $27^{\text {th }}$ Day of January 1858, and following days, London, 1859.

15. Sarkar, Chanchal, Amar Batarikakatar kahini (translated. Radhikamuhan Bhagbati, the story of our newspaper) national book trust, India ( ISBN 978-81-237-6356-9). New Delhi -110070. 1988. P.8.

16. Wilson, A. N. the Victorians, London, 2002 (reprinted edition. Arrow Book ltd, London. 2003.)

17. Ferguson Niall, Empire: How Britain Made the Modern World, London, 2003.

18. Tahir Dr. Masood, Urdu Saiafat Uniswin sadi Main (Karachi: Fazli Sons, 2003)

19. Siddiqui, Mohammad Attique, Hindūstāni Akhbār Nawīsī, Indus Publications, Karachi. 1980.

20. Naghmana Dr. Seemi and Baloch Dr. Munir Ahmed, War of Independence 1857 and role of Urdu and Persian newspapers. Internet collection Shudhganga.

21. Letter No.50, Copy of a Letter of the Chief Commissioner of Panjab, forwarding to the 
Governor General of India the Proceedings on the trial of the king of Delhi, India office 30 June 1859.

22. Dehlowi Shah Aliwallah, Hujjatullah-il-Balighah, Sayyid Mian Sahab, Ulama-e-Hind ka Shandar Madi,( The Glorious past of Indian Elites) Vol1,2,3,4. First edition 1957 and latest edition-2014, Faisal International New Dalhi.

23. Baqir Maulana Mohammmad, Delhi Urdu Akhbar issued. 14 دلهي اردو اخبار $14^{\text {th }}$ June 1857.

24. Siddique Muhammad Atique. هندستاني اخبار نويسي كمبني كى عهد مين (The Indian News Writings during the age of company.) Union printing press, Delhi, published by Anjuman-e-Taraqqui-e-Urdu (Hind) Alighar, 1957.

25. Azad Maulana Mahammad, Aab-e-Hayat,اب حيات first edition.1888. subsequent Edition. Khalifa Sayeed Muhammad Salim Mikhbar Azad Book خipu. Lahore (خليفه سيد محمد سالم ميخبر از اد بك دفو لاهور and نول كشور كيس printing Lahore 1907.

26. National Archive of India, Sirajul Akhbar, issued. 19 march 1857.

27. Delhi Urdu Akhbar دلهي اردو اخبار $14^{\text {th }}$ June 1857.

28. Delhi Urdu Akhbar دلهي اردو اخبار اخبار , 13 13 September 1857.

29. Faruque Aslam, Muhammad Hussain Azad. Vol- 1 Karachi 1965.

30. Eleventh day's proceeding Tuesday $9^{\text {th }}$ February 1858 , Copy of letter of the chief commissioner of Punjab, Forwarding to the Governor General of India the proceedings on the trial of the king of Delhi. Secretary in the political and secret Departments. India office 30 June 1859.

31. Thirteenth day's proceedings Thursday $11^{\text {th }}$ February 1858, Copy of letter of the chief commissioner of Punjab, Forwarding to the Governor General of India the proceedings on the trial of the king of Delhi. Secretary in the political and secret Departments. India Office 30 June 1859.

32. The Authentic News (Sadique ul Akhbar, No. IV.,Vol-III, Dated $26^{\text {th }}$ of January. Copy of a letter of the chief commissioner of the Punjab, forwarding to the Governor of India the proceedings on the trial of the king of Delhi, secretary in the political and secret department, India office 30 June 1859.

33. The Authentic News (Sadique Ul Akhbar) No. 11, Vol. 1ll, dated $16^{\text {th }}$ march 1857. Copy of a letter of the chief commissioner of the Punjab, forwarding to the Governor of India the proceedings on the trial of the king of Delhi, secretary in the political and secret department, India office 30 June 1859.

34. Sadique Ul Akhbar No. Xl, Vol. 1l, Dated $19^{\text {th }}$ March 1857.

35. Sadique Ul Akhbar no. XI, Vol 11l, Dated $23^{\text {rd }}$ March 1857.

36. Sadique Ul Akhbar, No. Vlll, Vol. IV, Dated $24^{\text {th }}$ August 1857.

37. Mohani Maulana Harat, Mushahidat-e- Zindan مشاهدات زندان) (Percipience of Prison) Guluri
Printers, Maulana Hasrat Mohani memorial society, Nazimabad Karachi, Pakistan. 1990.

38. Azad Maulana Abul Kalam, India wins freedom, Orient Blackswan Pvt. Ltd. New Delhi. 1988.

39. Hasan Mushirul, Roads to freedom. Oxford University Press, New Delhi. 2016

40. Mohani Maulana Hasrat, Kullyat-e-Harat. (Compelled. Begum Hasrat Mohani, wife of Hasrat Mohani), second edition, (Karachi: Hasrat memorial Hall and library, (1976) 1997.

41. Azhari Sayeed Ishtiaque, Preface of Mushahidat e Zindan (مشاهدات زندان) $7^{\text {th }}$ April 1990.

42. Gail Minault, The Khilafat Movement: religious symbolism and political mobilization in India. Columbia Press, New York. Isbn-10. 0231050720. 22 august 1982.

43. Halide Edib, Inside India, with an Introduction and notes by Mushirul Hasan (New Delhi: Oxford University Press, 2002.

44. Russell W. H., My Diary in India, Vol-I, London, 1860.

45. National Archives of India, Foreign Department, Political, November 1862.

46. National Archives of India, Mutiny Papers, Collection 56, no. 7.

47. Journal of the Pakistan Historical Society, Hakim Ahsanullah Khan, (The prime minister of Zafar ) Memoires, Vol. 6, pt 1,18, 58, Karachi, 1958.

48. Sadiq Ul- Akhbar, $10^{\text {th }}$ August 1857.

49. Metcalf. Charles Theophilus, Two Native Narratives of the Mutiny in Delhi, London, 1898.

50. Proceedings on the trial of Mouhammad Bahadur Shah, Titular King of Delhi, before a Military Commission, upon a charge of Rebellion, Treason and Murder, held at Delhi, on the $27^{\text {th }}$ Day of January 1858, and following days, Evidence of Ghulam Abbas, London. 1859.

51. National Archive of India, Mutiny Papers, collection 39.

52. Narrative of Chunni Lal, news-writer.

53. National Army Museum London, Col. Lieutenant Edward Ommaney's Letters and Diaries. 6301-143.

54. National Archive Of India, Mutiny Papers, Collection 57,59,60,61,62,63.

55. N.A. Chick, Annals of the Indian Rebellion 1857-8, Calcutta, 1859 (reprinted London 1972).

56. National Archive of India, Mutiny Papers, Collection 8, No.1, Entry for 20 May 1857.

57. Delhi Urdu Akhbar, issued 31 May 1857.

58. Oriental and India Office Collections, British Library, London, The city of Delhi during 1857 , translation of the account of Said Mobarak Shah, Account of Said Mubarak Shah, Eur Mss B, 138.

59. National Army Museum London, Wilson Correspondence, 5710-38, Wilson Letters, A.Wilson to his wife, Camp Ghzee Deen Nuggur, 30 May 1857.

60. National Army Museum London, Wilson Correspondence, 5710-38. Wilson Letters, AW to his wife, Camp Ghazee Deen Nuggur, 1 June 1857. 
61. Reid Major Charles, Defense of the Main piquet at Hindoo Rao's House as recorded by Major Reid Commanding the Sirmoor Battalion, London 1957.

62. National Archive of India, Mutiny Papers, Collection 126 no. 18 entry for 1 June 1857.

63. National Archive of India, Mutiny Papers, Collection 126, no 14 and 17. May 28 and 311857.

64. Latif Abdul, $1857 \mathrm{Ka}$ Tarikhi Roznamacha, ed. K.A. Nizami, Naqwatul Musannifin, Delhi, 1857, entry for 9 June 1857.

65. National Archive of India, Mutiny Papers, Collection 152, No. 43. For 7 June, 1857.

66. Dehlavi Zahir, Dastan-i-Ghadr:, داستان غدر يا ترز زاهري 1955.

67. Oriental and Indian Office Collections British Library, Account of Said Mobarak Shah London, Eur Mss B 138.

68. Rotton J. E. The chaplain's narrative of the siege of Delhi, London, 1858.

69. Hodson W.S.R. Twelve years of a soldiers life in India, London, 1859.

70. National Archive Of India, Mutiny Papers, Collection 128, no. 37, 12 June 1857.

71. NAI, Mutiny Papers, Collection 57, no. 185, 28 July 1857.

72. NAI, Mutiny Papers, Collection 61, no. 296, 4 August 1857.

73. NAI, Mutiny Papers, collection 61, no.396, 17 august 1857.

74. Lal Jewan, A Short account of the life and family of Rai Jiwan Lal Bahaur, late honorary magistrate of Delhi with extracts from his diary relating to the time of the mutiny 1857 compiled by his son , Delhi 1902.

75. NAI, Mutiny Papers, collection 57, no. 484, 12 September 1857.
76. Eliot and Dowsans History of India as told by their own historians. London 1858.

77. NAI, Mutiny Papers, Collection 100, no. 179.

78. Delhi Urdu Akhbar, $14^{\text {th }}$ July 1857.

79. Irfan Habib, The coming of 1857, in social scientist, Vol. 26. No. 1, 1998.

80. NAI, Mutiny Papers, Coll, 67. 77, $27^{\text {th }}$ July 1857.

81. NAI collection. 15, file no- 1 .

82. Mukherjee Rudrangshu, Auadh in Revolt 1857-8: A study of popular Resistance, New Delhi, 1984.

83. Khan Sir Sayyid Ahmad, Asar Us Sanadid, اثار الصناديد, vol.2. Delhi,1990.

84. Nizami Farhan Ahmad, Madrashas, scholars and Saints: Muslim Response to British presence in Delhi and the upper Doab 1803-1857, Oxford, 1983.

85. Colonel Geoge Bourchier, CB, Eight Months campaign against thr Bengal Sepoy army during the mutiny of 1857, London, 1858.

86. NAI, Mutiny Papers, Collection 15, no.19, early July 1857.

87. Griffiths, Charles John, The Siege of Delhi, London, 1910.

88. NAI, Mutiny Papers, Collection 16 , no $20,6^{\text {th }}$ September 1857.

89. NAI, Mutiny Papers, Collection 73, no.158, 8 September 1857.

90. OIOC, Montgomery Papers, no.198,.Mss Eur D 1019. 7 September 1857.

91. NAI, Mutiny Papers, Collection 16, no. 27.

92. OIOC, Montgomery Papers, Eur Mss D1019, no. 197, Delhee News, 31August 1857.

93. Greathed, H.H., Letters written during the siege of Delhi, London, 1858. 